RAFAŁ MAŃKO*

Uniwersytet Amsterdamski

\title{
PRAWO UŻYTKOWANIA WIECZYSTEGO JAKO POZOSTAŁOŚĆ PO EPOCE SOCJALIZMU REALNEGO - UJECIE SOCJOLOGICZNOPRAWNE
}

\section{WPROWADZENIE}

Jednym z pierwszych badaczy, którzy zwrócili uwagę na frapujące zjawisko ciągłości instytucji prawnych pomimo transformacji społeczno-gospodarczej i politycznej był austriacki socjolog prawa Karl Renner. W swej monografii poświęconej Instytucjom prawa prywatnego $i$ ich funkcjom społecznym z 1904 r. ${ }^{1}$ Renner zastanawiał się nad możliwością ciągłości tego, co określał mianem „formy prawnej” (a co rozumiał zasadniczo jako brzmienie przepisów prawnych) przy równoczesnej zmianie ich funkcji społecznej. Renner badał przemiany funkcji społecznej w XIX w., a ściślej w okresie przejścia od kapitalizmu drobnotowarowego do kapitalizmu monopolistycznego pod koniec tamtego wieku. Teoria Rennera nadaje się jednak, jak sądzę, do opisania zjawisk, jakie zaszły także w wieku XX, a w szczególności w następstwie upadku tzw. realnego socjalizmu. W większości państw dawnego obozu socjalistycznego utrzymano bowiem, przynajmniej w początkowym okresie,

*Artykuł wyraża jedynie osobiste poglądy Autora.

K. Renner, The Institutions of Private Law and Their Social Functions, tłum. A. Schwarzschild, London-Boston 1976 [1904]. 
ustawodawstwo cywilne pochodzące $\mathrm{z}$ okresu socjalistycznego ${ }^{2}$. Tak było i w Polsce.

Pomimo bowiem dość szeroko zakrojonych reform prawa prywatnego, w szczególności tzw. noweli czerwcowej z 1990 r. oraz noweli sierpniowej z 1996 r., nie usunięto szeregu instytucji prawnych o proweniencji PRL-owskiej ${ }^{3}$. W niniejszym artykule zamierzam dokładniej pochylić się nad jedną z takich instytucji - a mianowicie prawem użytkowania wieczystego, powołanym do życia w 1961 r. i do dziś funkcjonującym zarówno w porządku normatywnym (w kodeksie cywilnym, jak i ustawie o gospodarce nieruchomościami), jak i w obrocie prawnym.

Niniejszy artykuł ma charakter analizy socjologicznoprawnej - zbadam interesującą mnie instytucję nie w perspektywie dogmatycznej czy dogmatyczno-historycznej, ale w perspektywie relacji pomiędzy jej konstrukcją dogmatyczną a funkcją społeczną. Główną tezą artykułu jest stwierdzenie, że instytucja użytkowania wieczystego przetrwała z uwagi na zgodność jej funkcji społecznej po 1989 r. z nowymi uwarunkowaniami politycznymi i społeczno-gospodarczymi. Pozwoli mi to też na sformułowanie pewnych wniosków o charakterze ogólniejszym.

Artykuł składa się z siedmiu sekcji, wliczając w to wprowadzenie. W sekcji 2 przedstawiam metodologię badawczą (analizę użytkowania wieczystego qua reliktu prawnego); w sekcji 3 - ukazuję historyczne uwarunkowania pojawienia się tej instytucji; w sekcji 4 - analizuję przemiany jej konstrukcji dogmatycznej, sekcji 5 przybliżam w zarysie funkcjonowanie użytkowania wieczystego w praktyce obrotu, zaś w sekcji 6 pochylę się nad funkcją społecznej omawianej instytucji oraz jej

2 Do wyjątków należały m.in. była NRD, na której terytorium rozszerzono moc obowiązującą BGB, a także Estonia i Łotwa, które przywróciły prawo sprzed $1940 \mathrm{r}$.

3 Por. ogólny przegląd wybranych instytucji w pracach: R. Mańko, Demons of the Past? Legal Survivals of the Socialist Legal Tradition in Contemporary Polish Private Law, w: Law and Critique in Central Europe: Questioning the Past, Resisting the Present, red. R. Mańko, C.S. Cercel, A. Sulikowski, Oxford 2016; R. Mańko, Wybrane relikty prawne epoki realnego socjalizmu w polskim prawie cywilnym - analiza zmiany funkcji społecznej instytucji prawnych w następstwie transformacji ustrojowej, «Studia Iuridica» 66/2016. 
przemianom w następstwie transformacji ustrojowej. Sekcja 7 zawiera uwagi podsumowujące.

\section{Metodologia BAdAWCZA - POJĘCiE RELIKTU PRAWNEGO JAKO KLUCZ DO ANALIZY OMAWIANEJ INSTYTUCJI}

Analizy instytucji użytkowania wieczystego dokonam posługując się metodologią badania reliktów prawnych ${ }^{4}$, którą zaproponowałem $\mathrm{w}$ moich trzech wcześniejszych pracach. ${ }^{5}$ Jestem bowiem przekonany, że właśnie tego rodzaju metodologia - którą można, jak sądzę, zaliczyć do socjologii prawa sensu largo - pozwoli na lepsze zrozumienie istoty danej instytucji prawnej z szerokim uwzględnieniem jej kontekstu społecznego, politycznego i gospodarczego.

Pojęcie „reliktu prawnego” definiuję - nawiązując do K. Rennera jako: 1) określoną instytucję prawną, tj. zespół powiązanych ze sobą norm prawnych, włączając w to normy będące produktem prawotwórczej wykładni sądowej6; 2) którą to instytucję wprowadzono w warunkach wcześniejszej i zarazem jakościowo odmiennej formacji społeczno-ekonomicznej ${ }^{7}$; 3) która to instytucja - w chwili jej wprowadzenia

4 Pojęcie "reliktu prawnego" stanowi przekład pojęcia "legal survival” i ma charakter neutralny, tj. nie zawiera w sobie ujemnej oceny danej instytucji, kładąc jedynie nacisk na fakt, iż pozostała ona (łac. relinquere $\rightarrow$ relictus) niejako „w spadku” po minionym ustroju.

5 R. Mańko, Legal Survivals: A Conceptual Tool for Analysing Post-Transformation Continuity of Legal Culture w: Tiesību efektivitāte postmodernā sabiedrībāa, red. J. RoZENFELDS I IN., Riga 2015; IDEM, Relikty w kulturze prawnej. Uwagi metodologiczne na tle pozostałości epoki socjalizmu realnego w polskim prawie prywatnym, "Przegląd Prawa i Administracji» 102/2015; IDEM, Transformacja ustrojowa a ciagłość instytucji prawnych - uwagi teoretyczne, Zeszyty Prawnicze» 16.2/2016.

6 R. Mańко, Transformacja ustrojowa..., p. 11-17.

7 Por. co do użyteczności pojęcia formacji (ustroju) R. Mańko, Relikty..., s. 192193. Por. także krytyczne uwagi w pracy T. Giaro, Roman Law Always Dies With a Codification, w: Roman Law and European Legal Culture, red. A. DęBIŃsKi, M. JoŃCA, Lublin 2008, s. 22. 
- pełniła określoną funkcję $e^{8}$ relewantną z perspektywy tej formacji'; 4) która to instytucja przetrwała pomimo transformacji - przy czym „przetrwać” rozumiem tu nie tylko w płaszczyźnie obowiązujących norm prawnych, ale także płaszczyźnie ich rzeczywistego stosowania, tj. istnienia stosunków prawnych opartych na danej instytucji (in casu, istnienia i tworzenia podmiotowych praw użytkowania wieczystego $)^{10}$.

Konsekwencją takiego a nie innego rozumienia pojęcia reliktu prawnego jest określona metodologia badawcza ${ }^{11}$. Można powiedzieć, iż stanowi ona operacjonalizację teoretycznego pojęcia, jakim jest „relikt prawny”. Przede wszystkim przy badaniu reliktów prawnych niezbędne jest wyjście poza horyzont analitycznej nauki prawa ${ }^{12}$. W praktyce oznacza to, że instytucje prawne rozpatrywane jako relikty powinny być osadzone nie tylko w kontekście praktyki stosowania prawa, ale także w szerszym kontekście społeczno-gospodarczym, politycznym, a nawet ideologicznym. W przeciwnym wypadku nie będzie możliwe uchwycenie dynamiki funkcjonowania reliktów prawnych, w szczególności $\mathrm{w}$ fundamentalnym aspekcie przemiany ich funkcji społecznych.

Zakładając, że analiza reliktów prawnych może i powinna przebiegać według w miarę sformalizowanego protokołu badawczego, w niniejszym artykule przebadam interesującą mnie instytucję w trzech odrębnych płaszczyznach - po pierwsze, płaszczyźnie dogmatycznej (normatywnej); po drugie, płaszczyźnie praktyki obrotu (prawo w działaniu); po trzeciej, płaszczyźnie funkcji społecznych. Zarysowana we wprowadzeniu struktura artykułu odzwierciedla więc trzy zasadnicze płaszczyzny badawcze, w jakim obracać się powinna analiza reliktów prawnych: kontekst (społeczno-gospodarczy, polityczny, ideologiczny); tekst (forma

\footnotetext{
8 Pojęcie „funkcji” rozumiem tu jako rzeczywistą rolę społeczną danej instytucji prawnej, z uwzględnieniem jej wpływu na życie społeczne. Por. K. Renner, The Institutions..., s. 55; A. RedelbaCh, S. Wronkowska, Z. Ziembiński, Zarys teorii państwa i prawa, Warszawa 1994, s. 270; I. Bogucka, Funkcje prawa. Analiza pojęcia, Kraków 2000, s. 27-50, 67-93.

9 R. Mańko, Transformacja ustrojowa..., p. 22-28.

10 Ibidem, p. 18-21.

11 Por. w szczególności R. Mańko, Legal Survivals..., s. 26-27; Idem Relikty..., passim.

12 R. Mańko, Relikty..., s. 206-207.
} 
prawna, czyli konstrukcja dogmatyczna) oraz funkcja (scil. społeczna, a także jej przemiany). Połączenie wszystkich trzech elementów w jednym ujęciu badawczym pozwala, jak sądzę, na pełniejsze zrozumienie przyczyn, dla których określona instytucja o wyraźnym rodowodzie w minionym ustroju wciąż funkcjonuje w obrocie prawnym. Poza zakresem mojej analizy w niniejszym artykule pozostaje natomiast szerszy kontekst prawnoporównawczy ${ }^{13}$.

\section{HistORYCZNE UWARUNKOWANIA PRAWA UŻYTKOWANIA WIECZYSTEGO}

\subsection{Prawo rzeczowe a ideologia marksistowsko-leninowska}

Prawo rzeczowe epoki socjalizmu realnego pozostawało pod silnym wpływem oficjalnie głoszonej ideologii marksizmu-leninizmu. Uznawano potrzebę rozwijania własności państwowej, co traktowane było jako bezpośrednie wdrożenie poglądów wyrażonych przez K. Marksa i F. Engelsa w Manifeście komunistycznym, w którym to tekście bezpośrednio nawoływali do zniesienia własności prywatnej ${ }^{14}$. Po przewrocie bolszewickim przystąpiono z miejsca do realizacji tej wskazówki, czego przejawem był w szczególności Dekret o ziemi, znoszący prywatną własność nieruchomości gruntowych ${ }^{15}$. Należy ponadto zwrócić uwagę, że państwowa własność gruntów została w ZSRR podniesiona do rangi zasady konstytucyjnej ${ }^{16}$. W tych okolicznościach osoby prywatne za-

13 W szczególności poza zakresem moich rozważań pozostają ewentualne związki genetyczne polskiego użytkowania wieczystego w określonymi insytucjami prawa radzieckiego, a także pokrewieństwa rodzimej instytucji z jej odpowiednikami w innych państwach dawnego bloku państw socjalistycznych. Również poza zakresem rozważań pozostawiam porównanie użytkowania wieczystego w perspektywie historycznej, np. $\mathrm{z}$ instytucjami emphyteusis i ius superficies w prawie rzymskim.

14 K. Marx, F. Engels, The Communist Manifesto, London 2002 [1848], s. 235.

15 A. Litý́ski, Prawo Rosji i ZSRR 1917-1991 czyli historia wszechzwiązkowego komunistycznego prawa (bolszewików). Krótki kurs, Warszawa 2012, s. 216-219.

16 M. Lesage, Le droit soviétique, Paris 1975, s. 78; A. Lityński, Prawo Rosji..., p. 227. 
mierzające wznieść dom lub inny budynek nie mogły w żaden sposób nabyć własności gruntu pod nim się znajdującego. O ile budynek mógł stać się przedmiotem własności osobistej (pod warunkiem wszak, iż mieścił się w wyśrubwanych limitach co do jego powierzchni ${ }^{17}$, o tyle grunt musiał pozostawać własnością państwa.

\subsection{Poszukiwanie właściwej formy prawnej w Polsce (1944-1961)}

Po zaprowadzeniu w Polsce ustroju zwanego realnym socjalizmem, dominująca ideologia marksistowsko-leninowska $\mathrm{z}$ jej dogmatem państwowej własności nieruchomości zaczęła oddziaływać na prawo polskie. Choć nie zdecydowano się na radykalny krok w postaci nacjonalizcji ogółu nieruchomości gruntowych na wzór radziecki, przeprowadzono taką operację na terenie m.st. Warszawy ${ }^{18}$, w odniesieniu do własności niemieckiej w b. Wolnym Mieście Gdańsku, a także na całym obszarze Ziem Odzyskanych ${ }^{19}$. Do tego należy dodać nabycie przez państwo gruntów przy okazji nacjonalizacji kluczowych gałęzi przemysłu i handlu, a także nacjonalizację niektórych lasów ${ }^{20}$. Należy też podkreślić, że fundusz państwowej własności gruntów powiększał się wraz z upływem czasu, a to w związku z działamiem prawa pierwokupu ${ }^{21}$ oraz niezwykle szeroko podówczas zakrojonym przepisom prawa wywłaszczeniowego ${ }^{22}$.

W okresie pierwszych 15 lat powojennych socjalistyczny prawodawca wprowadzał kolejne instytucje prawne, które poprzedzały prawo użytkowania wieczystego. Pierwszym z nich było prawo zabudowy (recypowane z prawa niemieckiego), następnie własność czasowa ${ }^{23}$. Ostatecznie

17 M. Lesage, Le droit..., s. 79-80; W.E. Butler, Soviet Law, London 1983, s. 173.

18 Dekret z 26 października 1945 r. o własności i użytkowaniu gruntów na obszarze m. st. Warszawy (Dz.U. Nr 50, poz. 279).

19 Dekret z 8 marca 1946 r. o majątkach opuszczonych i poniemieckich. (Dz.U. Nr 13, poz. 87). Por. A. Machnikowska, Prawo własności w Polsce w latach 1944-1981. Studium historycznoprawne, Gdańsk 2010, s. 212-216.

20 Dekret Polskiego Komitetu Wyzwolenia Narodowego z 12 grudnia 1944 r. o przejęciu niektórych lasów na własność Skarbu Państwa (Dz.U. Nr 15, poz. 82).

21 A. Machnikowska, Prawo własności..., s. 402.

22 Ibidem, Prawo własności..., p. 511.

23 A. CISEK, Użytkowanie wieczyste w: System prawa prywatnego, IV: Prawo rzeczowe, red. E. GNIEWEK, Warszawa 2007, s. 140-141. 
zdecydowano się na stworzenie instytucji nowej, określonej mianem użytkowania wieczystego, które - jak trafnie zauważył Z. Gawlik - miało silne uwarunkowania ideologiczne i stanowiło w istocie „surogat” prawa własności ${ }^{24}$. Prawo użytkowania wieczystego w Polsce Ludowej miało na celu zachowanie w ręku państwa własności ziemi, przy równoczesnym stworzeniu bodźca skłaniającego obywateli do podejmowania inwestycji budowlanych $\mathrm{z}$ własnych funduszy w celu zaspokojenia swych potrzeb mieszkaniowych ${ }^{25}$. Nasuwa się w tym względzie nieodparta analogia do spółdzielczego własnościowego prawa do lokalu, którego ewolucję, także pod kątem uwarunkowań ideologicznych oraz zmiany funkcji społecznej, przedstawiłem we wcześniejszej pracy ${ }^{26}$.

Nakreśliwszy ideologiczne i polityczne okoliczności wprowadzenia do prawa polskiego instytucji użytkowania wieczystego, przejdę obecnie do omówienia jego formy prawnej oraz poddam analizie jej zmiany.

\section{Forma PRAWNA INSTYTUCJI UŻYTKOWANIA WIECZySTEgo}

\subsection{Prawo użytkowania wieczystego na gruncie ustawy z $1961 \mathrm{r}$.}

Prawo użytkowania wieczystego zostało powołane do życia przez ustawodawcę polskiego w roku $1961^{27}$. Jak zauważa Z. Gawlik, nie powstało ono „w próżni, lecz zastąpiło inne, pokrewne formy korzystania $\mathrm{z}$ nieruchomości państwowych", tj. własność czasową ${ }^{28}$. Użytkowanie wieczyste, choć stanowiło ius in re aliena, zdefiniowano w sposób dość

24 Z. GAWLIK, Użytkowanie wieczyste de lege ferenda [w:] Czterdzieści lat kodeksu cywilnego, red. M. SAWCZuK, Kraków 2006, s. 115.

25 B. Wierzbowski, Oprzydatności użytkowania wieczystego [w:] Honeste vivere... Księga pamiątkowa ku czci Profesora Władysława Bojarskiego, Toruń 2001, s. 618.

26 R. Mańko, The Cooperative Member's Proprietary Right to an Apartment: A Legal Survival of the Period of Actually Existing Socialism in Polish Private Law, «Zeszyty Prawnicze» 15.4/2015.

27 Ustawa z 14 lipca 1961 r. o gospodarce terenami w miastach i osiedlach (Dz.U. Nr 32, poz. 159, dalej jako: „u.g.t.”).

28 Z. GAWLIK, Użytkowanie wieczyste w świetle wypowiedzi Profesora Jerzego Ignatowicza, «Annales UMCS - Sectio G» 60.1/2013, s. 22. 
analogiczny do prawa własności, wskazując na takie jego elementy jak prawo dysponowania rzeczą $\mathrm{z}$ wyłączeniem innych osób $\mathrm{w}$ granicach określonych ustawą ${ }^{29}$. Prawo użytkowania wieczystego mogło zostać ustanowione (przez państwo) jedynie na terenie miast i osiedli, a także na terenach włączonych do miejskich planów zagospodarowania, nawet jeżeli nie znajdowały się w granicach administracyjnych miast i osiedli ${ }^{30}$. Użytkownikami wieczystymi mogły być osoby fizyczne oraz osoby prawne, z wyłączeniem jednak państwowych osób prawnych i jednostek gospodarki uspołecznionej ${ }^{31}$. Poza zakresem ustawy z 1961 r. znalazło się oddawanie gruntów w użytkowanie spółdzielniom mieszkaniowym i rolniczym spółdzielniom produkcyjnym ${ }^{32}$. Czas trwania użytkowania wieczystego określono na 99 lat, przy czym w wyjątkowych wypadkach mógł on być krótszy, jednakże nie krótszy niż lat $40^{33}$. W odróżnieniu od wcześniejszego prawa własności czasowej ustawodawca powołał więc do życia prawo długoterminowe, co uzasadniało użycie terminu „wieczysty” (99 lat to wszak - bez jednego roku - „wiek”). Kolejną różnicą konstrukcji dogmatycznej użytkowania wieczystego i własności czasowej było przyjęcie możliwości przedłużenia jako wariantu podstawowego, a odmowa takiego przedłużenia musiała być uzasadniona ważnym interesem publicznym ${ }^{34}$. Porównując więc dotychczasową własność czasową i użytkowanie wieczyste należy stwierdzić, że pomimo zmiany charakteru prawa (z własności w prawo na rzeczy cudzej) pozycja uprawnionego uległa wzmocnieniu w aspekcie trwałości stosunku prawnego.

Co się tyczy sposobu ustanowienia prawa użytkowania wieczystego, przyjęto model mieszany, kontraktowo-administracyjny. Prawo powstawało w wyniku zawarcia umowy pomiędzy przyszłym użytkownikiem wieczystym a organem administracji terenowej ${ }^{35}$, jednakże zawarcie takiej umowy poprzedzone było wydaniem decyzji administracyjnej

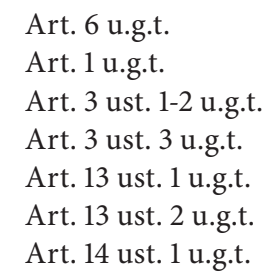


określającej szczegółowo treść umowy ${ }^{36}$. Przeznaczenie gruntu musiało być dookreślone w umowie i podlegało wpisowi do księgi wieczystej ${ }^{37}$. Jeżeli grunt miał być przeznaczony pod zabudowę, umowa musiała w szczegółowy sposób określić przyszłe budynki ${ }^{38}$.

Do obowiązków użytkownika wieczystego należało ponoszenie opłaty rocznej, której wysokość jednostronnie określał właściwy or$\operatorname{gan}^{39}$. Wysokość ta odpowiadać miała jakości infrastukturalnej oraz położeniu gruntu ${ }^{40}$.

Właściwy organ uprawniony był wypowiedzieć umowę w wypadku, gdyby użytkownik wieczysty korzystał z gruntu w sposób oczywiście sprzeczny z tym, co określono w umowie, lub gdyby nie wzniósł zabudowań, do których wzniesienia zobowiązał się w umowie ${ }^{41}$. Od decyzji organu służyła skarga do organu administracyjnego wyższego stopnia - w postępowaniu administracyjnym - nie przewidziano natomiast prawa skargi do sądu cywilnego ${ }^{42}$.

Prawo użytkowania wieczystego na gruncie ustawy z 1961 r. miało więc charakter hybrydowej instytucji prawnej, wpisującej się w szerszy kontekst zacierania podziału na prawo publiczne i prywatne w warunkach ustroju socjalistycznego ${ }^{43}$. Choć trzpień instytucji miał charakter cywilistyczny (konstrukcja ius in re aliena), otoczony był on elementami administracyjnoprawnymi (decyzja administracyjna poprzedzająca zawarcie umowy, tryb odwoławczy bez prawa do sądu cywilnego, jednostronne określanie wysokości opłaty rocznej przez organ), a także przesycony elementami chroniącymi interes publiczny (nacisk na społeczno-gospodarcze przeznaczenie gruntu). W tym sensie można wieć

\footnotetext{
${ }^{36}$ Art. 18 ust. 1-2 u.g.t.

37 Art. 17 ust. 1 u.g.t.

38 Art. 17 ust. 2 u.g.t.

39 Art. $24-25$ u.g.t.

40 J. Winiarz, Prawo użytkowania wieczystego, Warszawa 1970, s. 177-178.

41 Art..19 ust. 2 u.g.t.

42 Art. 19 ust. 3 u.g.t.

43 Por. szerzej o tym zjawisku: R. Mańko, „We Do Not Recognise Anything »Private ": Public Interest and Private Law Under the Socialist Legal Tradition and Beyond [w:] Private Interest and Public Interest in European Legal Tradition, red. B. SITEK I IN., Olsztyn 2015.
} 
powiedzieć, że analizowana instytucja prawna była symptomatyczna dla szerszych zjawisk właściwych ustrojowi realnego socjalizmu.

4.2. Prawo użytkowania wieczystego na gruncie Kodeksu cywilnego w brzmieniu pierwotnym

Z chwilą uchwalenia Kodeksu cywilnego z 1964 r. hybrydowość prawa użytkowania wieczystego nabrała nowego wyrazu. O ile w latach 19611964 prawo to niewątpliwie miało już charakter hybrydowy, o tyle jednak uregulowane było $\mathrm{w}$ pojedynczym akcie prawnym łączącym $\mathrm{w}$ sobie elementy prawa publicznego i prywatnego ${ }^{44}$. Ujęcie natomiast prawa użytkowania wieczystego w księdze II k.c. uwypukliło hybrydowość jego konstrukcji, albowiem przepisy prywatnoprawne znalazły się w k.c., natomiast publicznoprawne - pozostały w ustawie o gospodarce terenami ${ }^{45}$. Ta charakterystyczna dla socjalistycznej kultury prawnej dwutorowość regulacji omawianej instytucji utrzymała się zresztą do dziś.

Istotę prawa użytkowania wieczystego określono w k.c. podobnie, jak we wcześniejszej definicji w u.g.t. Art. 233 k.c. w brzmieniu pierwotnym stanowił: „W granicach określonych przez ustawy i zasady współżycia społecznego oraz przez umowę o oddanie terenu państwowego w użytkowanie wieczyste, użytkownik może korzystać z terenu z wyłączeniem innych osób. W tych samych granicach użytkownik wieczysty może swoim prawem rozporządzać." Warto zestawić tę definicję z definicją własności w art. 140 k.c. (kursywą zaznaczono frazy identyczne): „W granicach określonych przez ustawy i zasady współżycia społecznego właściciel może, $z$ wyłaczeniem innych osób, korzystać $z$ rzeczy zgodnie ze społeczno-gospodarczym przeznaczeniem swego prawa, w szczególności może pobierać pożytki i inne dochody z rzeczy. W tych samych granicach może rozporządzać rzeczą." Podstawowe różnice obu definicji sprowadzają się do tego, że w definicji własności w art. 140 k.c. wprowadzono dodatkowe ograniczenie, w postaci społeczno-gospodarczego przeznaczenia prawa własności, podczas gdy funkcję ograniczenia w definicji

44 Jak wiadomo, ówcześnie unikano określenia „prawo prywatne”, preferując z pobudek ideologicznych - określenie „prawo cywilne”.

45 J. Winiarz, Prawo..., p. 22-23. 
użytkowania wieczystego w art. 233 k.c. pełniła umowa o oddanie terenu państwowego w użytkowanie wieczyste.

Dodatkowym elementem podkreślającym szczególny status prawa użytkowania wieczystego było umiejscowienie przepisów regulujących tę instytucję w odrębnym tytule, pomieszczonym pomiędzy tytułem o prawie własności a tytułem o ograniczonych prawach rzeczowych ${ }^{46}$. W doktrynie akcentowano podobieństwa pomiędzy prawem użytkowania wieczystego a prawem własności, aprobując posługiwanie się per analogiam normami prawnymi regulującymi instytucję własności do instytucji użytkowania wieczystego ${ }^{47}$.

Stanowi to dodatkowy argument za tezą, iż socjalistyczne prawo użytkowania wieczystego nie było tylko prostym przedłużeniem starożytnej emfiteuzy czy germańskiego prawa zabudowy, lecz jakościowo nowym, oryginalnym wytworem zderzenia ideologii marksistowsko-leninowskiej z zachodnią tradycją prawną, do jakiego doszło w Polsce po 1944 r. Jak trafnie wskazał A.W. Rudziński, było więc ono „raczej niekonwencjonalną instytucją prawną"48.

Prawo użytkowania wieczystego było nowe nie tylko z nazwy, ale także było istotowo odmienne od podobnych instytucji prawa zachodniego, co wynikało z dwóch czynników - ideologicznego (odmienne funkcje ideologiczne) oraz dogmatycznego (odmienna konstrukcja dogmatyczna, przeplatająca elementy prywatno-i publicznoprawne).

Co istotne, prawo użytkowania wieczystego zachowało swój hybrydowy charakter przez cały okres realnego socjalizmu ${ }^{49}$. W szczególności powstanie, zmiana i wygaśnięcie prawa użytkowania wieczystego musiały zawsze być poprzedzone odpowiednią decyzją administracyjną ${ }^{50}$.

46 A.W. Rudziński, A Comparative Study of Polish Property Law, [w:] Polish Civil Law, I, red. D. LAsok, Leiden 1973, s. 71-72.

47 A. Cisek, Użytkowanie..., s. 146.

48 A.W. Rudziński, A Comparative..., s. 70.

49 A. Cisek, Użytkowanie..., s. 144. B. Wierzbowski podkreśla trudności w oddzieleniu od siebie komponentów prywatnoprawnych i publicznoprawnych, a także elementów dominium i imperium (B. Wierzbowski, O przydatności..., s. 618-619).

50 A. Cisek, Użytkowanie..., s. 144. 
Można by co prawda twierdzić, że niemal każda instytucja prawa prywatnego ma swoje określone odzwierciedlenie w prawie publicznym, tak iż czynność konwencjonalna podjęta w oparciu o normy prawne wchodzące w skład danej instytucji prawa prywatnego wywierają też (częstokroć) pewne skutki publicznoprawne, tzn. że powstają równocześnie dwa paralelne stosunki prawne - stosunek prywatnoprawny i stosunek publicznoprawny. Jako przykład można by przy toczyć umowę sprzedaży i równoczesne powstanie obowiązku podatkowego w zakresie, odpowiednio, albo podatku VAT albo podatku od czynności cywilnoprawnych. Podobnie np. zabór cudzego mienia jest równocześnie czynem niedozwolonym, jak i kradzieżą, wobec czego ta sama czynność faktyczna rodzi zarówno stosunek cywilnoprawny, jak i karnoprawny. W wypadku jednak hybrydowej instytucji prawnej, jaką było (i wciąż częściowo jest) prawo użytkowania wieczystego, elementy prawa prywatnego i publicznego (tzn. normy prawne należące do obu tych gałęzi prawa) przeplatają się ze sobą $w$ obrębie samej istoty tej instytucji prawnej. Hybrydowość oznacza więc - jak widać to na przykładzie omawianej instytucji - połączenie norm prawa prywatnego i publicznego w ramach konstrukcji samej instytucji, a nie tylko (jak w przytoczonych wyżej przykładach) fakt regulowania tego samego stanu faktycznego przez różne zbiory norm (prawa publicznego i prywatnego). Stawiam hipotezę, że taka właśnie istotowa hybrydowość instytucji użytkowania wieczystego stanowi o jej wyjątkowości ${ }^{51}$ i odmienności od wcześniejszych form prawnych (w zachodniej tradycji prawnej), a równocześnie jest symtomatyczna dla warunków ustrojowych, które tę instytucję zrodziły, a które cechowało dążenie do zanegowania podziału na prawo publiczne i prywatne ${ }^{52}$.

4.3. Prawo użytkowania wieczystego po $1990 \mathrm{r}$.

Po upadku realnego socjalizmu i restauracji kapitalistycznego ustroju społeczno-gospodarczego w Polsce, instytucja prawa użytkowania wieczystego zaczęła przechodzić charakterystyczną ewolucję która - jak

51 Terminu „wyjątkowość” (podobnie jak terminu „relikt”) używam tu w znaczeniu neutralnym.

52 Por. R. Mańko, „We Do Not...”. 
twierdzę - może zostać określona jako adaptacja socjalistycznego reliktu prawnego do nowych, kapitalistycznych stosunków. Kluczowym elementem tej ewolucji jest stopniowe ograniczenie komponentów publicznoprawnych (co można określić mianem „depubublicyzacji” tej instytucji prawnej), w kierunku uczynienia $\mathrm{z}$ niej instytucji czysto prywatnoprawnej. Tym niemniej, wciąż nie pozbyto się elementu dwutorowości regulacji, która pozostaje podzielona pomiędzy Kodeks cywilny a ustawę o gospodarce nieruchomościami (u.g.n.) ${ }^{53}$.

Aktualnie - podobnie jak w okresie realnego socjalizmu ${ }^{54}$ - prawo użytkowania wieczystego zostaje ustanowione w drodze umowy pomiędzy podmiotem publicznym (dziś: Skarbem Państwa albo jednostką samorządu terytorialnego) a osobą fizyczną lub prawną ${ }^{55}$. Wymóg formy aktu notarialnego przewidziano w art. 27 u.g.n. Znakiem czasów jest zastąpienie - w roli czynności poprzedzającej zawarcie umowy - (jednostronnej) decyzji administracyjnej przez (z natury wielostronne) postępowanie przetargowe (art. 28 u.g.n.) ${ }^{56}$, choć w u.g.n. przewidziano wyjątki od tego trybu (art. 37 u.g.n.) Nadal umowa może zobowiązywać użytkownika wieczystego do wznienia budynku lub czynienia w określony sposób użytku z gruntu (art. 29 u.g.n., art. 236 i 239 k.c.) $)^{57}$. Takie ograniczenie można uznać za jeden z istotnych przejawów ciągłości omawianej instytucji prawnej. Oczywiście, jak wskazywałem już niejednokrotnie ${ }^{58}$, sam fakt takiej ciągłości nie jest sam przez się negatywny i nie powinien być z tego powodu czyniony instytucji użytkowania wieczystego zarzut. Przeciwnie, jak wskazuję w dalszych rozważaniach, postanowienia umowne ograniczające swobodę użytkownika wieczystego mogą być interesującym instrumentem planowania przestrzennego w interesie publicznym.

53 Ustawa z 21 sierpnia 1997 r. o gospodarce nieruchomościami (tekst jednolity: Dz.U. z 2015 r., poz. 1774).

54 Z zastrzeżeniem oczywiście wyodrębnienia jednostek samorządu terytorialnego jako podmiotów mających własną osobowość prawną.

55 A. Cisek, Użytkowanie..., s. 151.

56 Ibidem, s. 152-153.

57 Ibidem, s. 157.

58 Por. np. R. MAŃko, Demons..., s. 88-89. 
Co charakterystyczne - i poniekąd paralelne z ewolucją spółdzielczego własnościowego prawa do lokalu po $1989 \mathrm{r} .^{59}$ - zniesiono istotną część ograniczeń, krępujących autonomię woli stron w zakresie prawa użytkowania wieczystego. W szczególności zniesiono ograniczenia przedmiotowe (prawem użytkowania wieczystego mogą być objęte nie tylko grunty miejskie, ale wszelkie grunty - w tym rolne), a także podmiotowe (dowolna osoba fizyczna lub prawna może stać się użytkownikiem wieczystym ${ }^{60}$. Trwa natomiast nadal ograniczenie podmiotowe po stronie właściciela obciążającego swą nieruchomość użytkowaniem wieczystym - nadal nie może tego uczynić dowolna osoba fizyczna lub prawna.

Zagadnienie opłaty rocznej (art. 72-73 u.g.n.) ukształtowano obecnie w sposób odwołujący się do rynkowej wartości gruntu - co stanowi kolejny symptom adaptacji omawianej instytucji prawnej do kapitalistycznych stosunków społeczno-gospodarczych. Zasadniczo pierwsza opłata (jednorazowa) wynosi od 15 do $25 \%$ wartości gruntu, a następnie opłaty roczne wynoszą, co do zasady, 3\% wartości gruntu (wysokość podstawowa), choć ustawodawca przewidział też opłaty obniżone w wysokości $0.3,1 \%, 2 \%$ wartości gruntu ${ }^{61}$. Najbardziej preferencyjną stawkę $(0,3 \%)$ przewidziano dla działalności religijnej, kulturalnej i charytatywnej. Ponad trzy razy wyższą stawkę (1\%) przewidziano dla budownictwa mieszkaniowego. Wreszcie stawkę $2 \%$ przewidziano dla działalności turystycznej.

Istotnemu wzmocnieniu uległa - w stosunku do okresu PRL - pozycja prawna użytkownika wieczystego względem właściciela. W razie bowiem korzystania z gruntu niezgodnie z postanowieniami umowy właściciel (obecnie: Skarb Państwa bądź jednostka samorządu terytorialnego) wystąpić musi na drogę sądową, żądając rozwiązania umowy, co skutkuje zgaśnięciem prawa użytkowanai wieczystego (art. 240 k.c.) ${ }^{62}$.

59 Por. R. Mańko, Cooperative..., s. 167-172.

${ }^{60}$ G. Bieniek, W sprawie przyszłości użytkowania wieczystego, [w:] Ars et usus. Księga pamiątkowa ku czci Sędziego Stanisława Rudnickiego, Warszawa 2005, s. 54.

${ }_{61}$ A. Cisek, Użytkowanie..., s. 173.

62 Ibidem, s. 180. 
Nie ma więc już mowy o jednostronnym zakończeniu stosunku prawnego przez organ władzy państwowej, jak to miało miejsce uprzednio.

Należy odnotować, że w okresie III RP trzykrotnie uchwalano ustawy mające na celu umożliwienie użytkownikom wieczystym nabycie własności gruntu obciążonego ich prawem rzeczowym ${ }^{63}$. Były to, kolejno: ustawa z dnia 4 września 1997 r. o przekształceniu prawa użytkowania wieczystego przysługującego osobom fizycznym w prawo własności ${ }^{64}$; ustawa $\mathrm{z}$ dnia 26 lipca 2001 r. o nabywaniu przez użytkowników wieczystych prawa własności nieruchomości ${ }^{65}$, wreszcie obowiązująca do dziś - po nowelizacjach - ustawa z dnia 29 lipca 2005 r. o przekształceniu prawa użytkowania wieczystego w prawo własności nieruchomości ${ }^{66}$.

Szczegółowe omówienie tych trzech ustaw, ich kolejnych nowelizacji, jak też orzecznictwa Trybunału Konstytucyjnego dotyczącego ich zgodności z Konstytucją wykraczałoby niewątpliwie poza ramy niniejszego artykułu, także z tej przyczyny, że przepisy te mają na celu eliminację stosunków prawnych powstałych na podstawie norm składających się na omawiany relikt. Tymczasem celem niniejszego artykułu jest ukazanie ciągłości użytkowania wieczystego jako instytucji prawnej, czego przejawem jest zarówno dalsze obowiązywanie norm prawnych, z których jest ona skonstruowana, jak i dalsze wykorzystywanie tych norm przejawiające się w istnieniu stosunków prawnych użytkowania wieczystego względnie powoływania takich stosunków do życia poprzez ustanowienie omawianego prawa.

Z perspektywy więc prowadzonych tu rozważań trzy omawiane akty prawne - w tym ostatni $\mathrm{z}$ nich, aktualnie pozostający w mocy - interesujące będą o tyle tylko, o ile przyczyniają się do zmniejszenia bądź wyeliminowania stosunków prawnych użytkowania wieczystego. Nie są więc one przedmiotem zainteresowania w swej płaszczyźnie normatywnej (tj. w płaszczyźńie treści obowiązującego prawa), lecz jedynie

${ }^{63}$ Z obszernej literarury por. np. P. PoDLEś, Przekształcanie prawa użytkowania wieczystego w prawo własności, Warszawa 2007.

64 Dz. U. z 2001 r. Nr 120, poz. 1299 oraz z 2002 r. Nr 113, poz. 984.

65 Dz. U. Nr 113, poz. 1209, z 2002 r. Nr 113, poz. 984 oraz z 2003 r. Nr 3, poz. 24 i Nr 64, poz. 592 .

${ }^{66}$ Tekst jedn. Dz.U. z 2012 r., poz. 83. 
w płaszczyźnie stosowania prawa (tj. istniejących stosunków prawnych) i to o tyle tylko, o ile mogłyby one zagrozić stosowaniu instytucji prawa użytkowania wieczystego (co w konsekwencji doprowadziłoby do tego, iż stałaby się ona tzw. reliktem pozornym, istniejącym w sferze przepisów prawnych - law in books - ale nie w sferze praktyki stosowania prawa - law in action ${ }^{67}$. Stosowne statystyki zostaną przytoczone w kolejnej sekcji artykułu.

\section{Prawo uŻytKowania Wieczystego W PraktyCe Obrotu}

W chwili pisania niniejszego artykułu instytucja prawa użytkowania wieczystego liczyła sobie już 55 lat (1961-2016). Nie dziwi więc pogląd wyrażony przez Z. Gawlika, iż instytucja ta zyskała akceptację społeczną ${ }^{68}$. Także dane statystyczne wskazują, że prawo użytkowania wieczystego występuje szeroko w obrocie, choć można zaobserwować pewną tendencję malejącą, gdy chodzi o udział tego prawa w gminnym zasobie nieruchomości.

I tak, w 2011 r. spośród ogółu czynności prawnych dotyczących nieruchomości zarejestrowanych w statystykach GUS, umowy o ustanowienie prawa użytkowania wieczystego stanowiły $2,9 \%$ ogółu transakcji, zaś umowy o zbycie (już istniejącego) prawa - 1,5\% ogółu transakcji ${ }^{69}$.

Z kolei pod względem obszarowym należy odnotować, jak już wspomniałem, lekki acz konsekwentny spadek udziału gruntów objętych użytkowaneim wieczystym w obrębie całości areału gminnej własności gminnej w Polsce ${ }^{70}$. W roku 2014 r. użytkowaniem wieczystym obciążone

67 O pojęciu „reliktu pozornego” por. R. Мańko, Relikty..., s. 196-199.

68 Z. GAWLIK, Użytkowanie..., p. 116.

69 GŁówny Urząd Statystyczny, Obrót nieruchomościami w 2011 r., Warszawa 2012, dostępne: http://www.stat.gov.pl/cps/rde/xbcr/gus/IK_obrot_nieruchomosciamii_2011.pdf, s. 11. dostęp 4 października 2016 r.

70 Powierzchniagruntów komunalnych wg prawnych form użytkowania, portal «Moje Państwo» dostępne: https://mojepanstwo.pl/dane/bdl_wskazniki/838,powierzchnia-gruntow-komunalnych-wg-prawnych-form-uzytkowania, dostęp 4 października $2016 \mathrm{r}$. 
było 77.447,9 ha, podczas gdy w 2013 r. - 78.084,3 ha, w 2012 r. -79.829 ha, w 2011 r. - 81.417,5 ha, zaś w 2010 r. - 83.471,3 ha. Należy przy tym podkreślić, że spadek owego areału zbiega się w czasie z ogólnym wzrostem zasobu nieruchomości gminnych, który w 2014 r. liczył sobie 858.872,4 ha (podczas gdy w 2010 r. - jedynie 791.489,5 ha). Oznacza to, że udział gruntów należących do zasobu nieruchomości gminnych obciążonych prawem użytkowania wieczystego zmniejszył się z 10,5\% w 2010 r. do 9\% w 2014 r. Niewątpliwie, jest to m.in. skutek funkcjonowania w praktyce przepisów o nabywaniu prawa własności nieruchomości przez użytkowników wieczystych, o których była mowa wyżej.

Przychód z tytułu opłat za użytkowanie wieczyste stanowi - po doliczeniu przychodu z tytułu opłat za użytkowanie (zwykłe) oraz dochodów za zarządzenie nieruchomości - 9\% przychodu miast na prawach powiatu ${ }^{71}$.

Z kolei według danych Głównego Urzędu Statystycznego dotyczących transakcji kupna-sprzedaży nieruchomości w 2014 r. ${ }^{72}$, wśród nieruchomości zabudowanych 10,5\% transakcji dotyczyło zbycia prawa użytkowania wieczystego (8838 nieruchomości spośród ogólnej liczby 84236 nieruchomości). Co się tyczy wartości takich nieruchomości, warto odnotować, że nieruchomości objęte użytkowaniem wieczystym były więcej warte (stanowiąc 16,5\% ogółu transakcji pod względem wartości), choć były mniejsze obszarowo (stanowiąc 4,6\% ogółu powierzchni nieruchomości zbywanych w 2014 r.). Interesujące są także dane dotyczące rodzaju nieruchomości zabudowanych. W statystyce GUS podzielono je według rodzaju budynków - mieszkalnych, zabudowań rolnych oraz pozostałych zabudowań (przemysłowych, składowych itp.). Nieruchomości objęte użytkowaniem wieczystym stanowiły - spośród ogółu

71 Dane za 2009 r. GŁówny UrząD Statystyczny, Budżety jednostek samorządu terytorialnego, Warszawa 2010, http://www.stat.gov.pl/cps/rde/xbcr/gus/PUBL_rn_ budz_jedn_sam_teryt_lata_2003-2009.pdf, dostęp 10 listopada 2013 r. W późniejszych zestawieniach (np. za 2014) nie wyszczególniono odrębnie dochodu z tytułu opłaty za użytkowanie wieczyste.

72 GŁówny Urząd Statystyczny, Obrót nieruchomościami w 2014 r., Warszawa 2015, http://stat.gov.pl/files/gfx/portalinformacyjny/pl/defaultaktualnosci/5492/4/12/1/ obrot_nieruchomosciami_w_2014.pdf, s. 96, dostęp 4 października 2016 r. 
transakcji kupna-sprzedaży zawartych w 2014 r. - 6,1\% nieruchomości zabudowanych budynkami mieszkalnymi, 0,7\% gruntów rolnych zabudowanych oraz aż 30,6\% nieruchomości zabudowanych innymi budynkami (nierolnymi i niemieszkaniowymi). Szczególna ta ostatnia liczba dowodzi, jak istotne pozostaje prawo użytkowania wieczystego w obrocie a także pokazuje - o czym będzie mowa niżej - iż jego funkcja społeczna przesuwa się z funkcji pozyskiwania gruntów pod budownictwo mieszkaniowe (głównej funkcji w okresie PRL) w kierunku funkcji pozysykiwania gruntów pod inwestycje przedsiębiorstw.

Gdy chodzi o nieruchomości gruntowe niezabudowane, liczba transakcji dotyczących prawa użytkowania wieczystego była mniejsza niż w wypadku nieruchomości zabudowanych ${ }^{73}$. Spośród ogółu nieruchomości było to $1,6 \%$, natomiast w wypadku nieruchomości przeznaczonych pod zabudowę - 4,7\%. Udział ten był jeszcze wyższy w wypadku nieruchomości przeznaczonych pod zabudowę przemysłową, wynosząc $9,6 \%$.

Biorąc pod uwagę tak znaczną skalę występowania prawa użytkowania wieczystego w praktyce obrotu nie dziwi znaczna liczba orzeczeń dotyczących tego prawa, zapadających przed wyższymi sądami. Tematyka niedawnych orzeczeń dotyczyła m.in. synalagmatyczności umowy o ustanowienie prawa użytkowania wieczystego ${ }^{74}$, możliwości zasiedzenia gruntu obciążonego tym prawem ${ }^{75}$, charakteru prawnego opłaty rocznej $^{76}$, możliwości zasiedzenia prawa użytkowania wieczystego ${ }^{77}$, możliwości ustanowienia służebności przejazdu pomiędzy użytkownikami wieczystymi ${ }^{78}$, możliwości wzniesienia budynku częściowo na gruncie objętym użytkowaniem wieczystym ${ }^{79}$, relacji pomiędzy prawem użytkowania wieczystego a własnością wód na gruncie prawa wodnego ${ }^{80}$,

73 Geówny Urząd Statystyczny, Obrót nieruchomościami..., s. 140.

74 Wyrok SA w Warszawie z 6 lutego 2013 r., sygn. akt VI ACa 1236/12, «Lex» nr 1344292.

75 Postanowienie SN z 14 marca 2012 r., sygn. akt II CSK 127/11, «Lex» nr 1170220.

76 Wyrok SN z 25 listopada 2010 r., sygn. akt I CSK Case 692/09, «Lex» nr 736524.

77 Postanowienie SN z 24 czerwca 2010 r., sygn. akt IV CSK 553/09, «Lex» nr 885034.

78 Postanowienie SN z 15 maja 2009, sygn. akt II CSK 674/08, «Lex» nr 519243.

79 Wyrok SN z 11 stycznia 2013 r., sygn. akt I CSK 282/12, «Lex» nr 1288603.

80 Wyrok SN z 25 października 2012 r., sygn. akt I CSK 145/12, «Lex» nr 1281378. 
czy też własności budynku wzniesionego przez dzierżąwcę na gruncie objętym użytkowaniem wieczystym ${ }^{81}$.

\section{EWOLUCJA FUNKCJI SPOŁECZNEJ PRAWA UŻYTKOWANIA WIECZYSTEGO}

6.1. Funkcje społeczne użytkowania wieczystego w okresie PRL

W okresie realnego socjalizmu prawo użytkowania wieczystego pełniło szereg funkcji, które można podzielić na polityczno-ideologiczne i społeczno-gospodarcze. Jeśli chodzi o funkcje polityczno-ideologiczne, należy podkreśłić, że prawo to pozwalało realizować dogmat ideologii marksistowsko-leninowskiej o państwowej własności gruntów. Miało to też, jak wolno sądzić, znaczenie polityczne, bowiem - w odróżnieniu od własności - prawo użytkowania wieczystego było słabszym tytułem prawnym, w szczególności z uwagi na możliwość jego jednostronnego wygaszenia przez organ administracji państwowej.

Funkcją społeczno-gospodarczą z kolei było zarządzanie gruntami państwowymi poprzez przeznaczenie ich na cele budownictwa mieszkaniowego (zwłaszcza spółdzielczego), rozwój infrastruktury turystycznej, jak też innych celów (np. tworzenie terenów sportowych, placów zabaw itp.), a nawet dla celów wspierania produkcji rolnej ${ }^{82}$. Spośród tych celów na plan pierwszy konsekwentnie wysuwało się budownictwo mieszkaniowe $^{83}$. Należy przy tym odnotować, że poprzez instytucję użytkowania wieczystego państwo skłaniało obywateli do zaangażowania własnych środków dla potrzeb zaspokojenia potrzeb mieszkaniowych ${ }^{84}$. Nasuwa się bezpośrednie skojarzenie ze spółdzielczym własnościowym pra-

81 Uchwała SN z 25 listopada 2011 r., sygn. akt III CZP 60/11, «Lex» nr 1027882.

82 A. Cisek, Użytkowanie..., s. 143.

83 J. Winiarz, Prawo użtkowania..., s. 34; E. Gniewer, Prawo rzeczowe ${ }^{2}$, Warszawa 1999, s. 162-163; A. Cisek, Użytkowanie..., s. 143; K. Pietrzy kowski, [w:] Kodeks cywilny. Komentarz do artykułów 1-449 ${ }^{11}$, red. K. Pietrzy KowsKi, Warszawa 2005, s. 654; Z. GAWLIK, Użytkowanie wieczyste..., s. 23.

${ }^{84}$ B. Wierzbowski, O przydatności..., s. 618. 
wem do lokalu, które również służyło m.in. przekierowaniu strumenia środków oddanych do dyspozycji obywatelom z odcinka konsumpcji na odcinek inwestycji (budownictwa mieszkaniowego) ${ }^{85}$. Równocześnie realizacja tak określonej funkcji społeczno-gospodarczej nie zagrażała państwowemu funduszowi własności gruntów, co - jak podkreśla E. Gniewek - stanowiło istotny czynnik ideologiczny ${ }^{86}$.

Ponadto, jak zauważył Z. Gawlik, w okresie PRL prawo użytkowania wieczystego było przyznawane przez władze w sposób uznaniowy, co jak pisze - „czyniło z omawianego prawa niekiedy »nagrodę« dla osób "zasłużonych" w ocenie ówczesnego dysponenta nieruchomości będących własnością Skarbu Państwa." ${ }^{87}$ Można to określić mianem funkcji politycznej (ułatwiającej sprawowanie władzy politycznej w państwie) omawianej instytucji, dającej się odróżnić od funkcji ideologicznej z jednej strony, oraz od funkcji społeczno-gospodarczych z drugiej strony. Takie zjawisko wydaje się symptomatyczne dla ustroju realnego socjalizmu w którym - jak trafnie podkreśla B. Schönfelder - zanegowano dyferencjację funkcjonalną na systemy (w rozumienia Luhmannowskim): prawny, polityczny i gospodarczy, albowiem nad systemem prawnym i gospodarczym z samego założenia dominował system polityczny ${ }^{88}$.

Patrząc z kolei na funkcję społeczną użytkowania wieczystego z perspektywy obywateli i spółdzielni mieszkaniowych należy zauważyć, że polegała ona przede wszystkim na umożliwieniu uzyskania trwałego dostępu do gruntu. Należy podkreślić, że instytucja prawa użytkowania wieczystego stanowiła w praktyce bardzo istotny tytuł prawny dla spółdzielni mieszkaniowych ${ }^{89}$, które odgrywały istotną rolę w zakresie budownictwa wielorodzinnego w PRL ${ }^{90}$. Także osoby fizyczne wzno-

85 R. Mańko, Cooperative proprietary..., s. 151.

86 E. GNIEweK, Prawo rzeczowe, s. 163.

87 Z. GAWLIK, Użytkowanie wieczyste..., s. 25.

88 B. SCHÖNFELDER, The evolution of law under communism and post-communism: a system-theory analysis in the spirit of Luhmann, «Financial Theory \& Practice» 40.3/2016, s. 299.

89 J. Winiarz, Prawo użytkowania..., s. 37.

90 M. Cesarski, Dorobek materialny społdzielczości mieszkaniowej w Polsce, w: Historia i przyszłość społdzielczości mieszkaniowej w Polsce red. Z. Gotfalski, Warszawa 2011, s. 29. 
siły domy jednorodzinne na gruncie pozostającym w ich użytkowaniu wieczystym ${ }^{91}$.

6.2. Funkcje społeczne użytkowania wieczystego po tranformacji ustrojowej

W okresie po transformacji ustrojowej w 1989 r. funkcje społeczne prawa użytkowania wieczystego uległy charakterystycznym przemianom. Przede wszystkim odpadły funkcje ideologiczno-polityczne, charakterystyczne dla tej instytucji w okresie PRL, polegające na dążeniu do utrzymania i maksymalizacji państwowej własności gruntów. Należy odnotować, że od 1990 r. szeroko dopuszczono zbywanie gruntów publicznych na rzecz podmiotów prywatnych ${ }^{92}$.

Pojawiła się natomiast nowa, istotna w warunków gospodarki rynkowej, funkcja ekonomiczna prawa użytkowania wieczystego, polegająca na zapewnieniu jednostkom samorządu terytorialnego stałego źródła dochodów (w postaci opłat rocznych) które, po kilkudziesięciu latach, mogą przekroczyć rynkową wartość nieruchomości ${ }^{93}$. Mają one charakter sui generis renty gruntowej ${ }^{94}$. Ponadto należy wskazać na funkcję planistyczną użytkowania wieczystego - oddanie gruntu w użytkowanie wieczyste zamiast jego sprzedaży pozostawia w gestii władz gminy większy zakres kontroli nad sposobem użytkowania gruntu ${ }^{95}$. Jak zauważa Z. Gawlik powołując się na poglądy J. Ignatowicza, prawo uży tkowania wieczystego „realizuje obecnie szereg różnych zadań. Dzięki użytkowaniu wieczystemu [jednostki samorządu terytorialnego] mogą sobie [...] zapewnić możliwość realizacji [określonych] celów przy równoczesnym ustanowieniu koniecznych, a zarazem wystarczających narzędzi do kontroli sposobów ich realizacji. [...] W sytuacji wybrania pośredniego sposobu udostępnienia nieruchomości stanowiącej własność publiczną,

91 J. Winiarz, Prawo użytkowania..., s. 38.

92 Umożliwiła to ustawa z 29 września 1990 r. o zmianie ustawy o gospodarce gruntami i wywłaszczaniu nieruchomości (Dz. U. Nr 79, poz. 464), która weszła w życie 5 grudnia $1990 \mathrm{r}$.

93 A. CISEK, Użytkowanie..., s. 145.

94 Z. GAWLIK, Użytkowanie wieczyste..., s. 27.

95 B. Wierzbowski, O przydatności..., s. 621. 
władza korzysta z określonego typu gwarancji i zabezpieczeń, że wykorzystanie tej nieruchomości nie będzie rozbieżne z oczekiwaniem właściciela nieruchomości i nie straci on nigdy kontroli nad tym, w jaki sposób nieruchomość ta jest wykorzystywana." ${ }^{\text {96 }}$

Patrząc z perspektywy osób fizycznych i prawnych - użytkowników wieczystych - można także odnotować zmianę funkcji społecznej z pierwotnej, polegającej na pozyskaniu gruntu w ogóle (przy trudnościach z nabyciem gruntu państwowego na własność) na funkcję polegającą na uzyskaniu tańszego dostępu do gruntu (w porównaniu z nabyciem prawa własności ${ }^{97}$. Określoną rolę przy wyborze prawnej formy korzystania z gruntu (prawo własności czy użytkowanie wieczyste) odgrywają czynniki ekonomiczne i księgowe ${ }^{98}$, a także porównanie kosztów kredytu bankowego i kosztów opłaty rocznej (w odpowiedniej skali czasowej). Z. Gawlik podkreśla, że funkcja społeczna prawa użytkowania wieczystego polegająca na „ułatwieni[u] pozyskania nieruchomości pod inwestcje [...] współcześnie wzrasta wobec niestabilnego rynku nieruchomości oraz pewnej zapaści w obszarze inwestycji, zwłaszcza na drążący nie tylko Polskę kryzys gospodarczy." ${ }^{99}$ Co godne podkreślenia, prawo użytkowania wieczystego częstokroć weszło w skład majątku prywatyzowanych przedsiębiorstw państwowych, a uczestniczący $\mathrm{w}$ procesie prywatyzacji inwestorzy zagraniczni nie byli zniechęceni faktem, że nabywają ius in re aliena, i to ograniczone terminem, a nie prawo własności ${ }^{100}$. Nawiasem mówiąc, można przypuszczać, że dla inwestorów z państw systemu common law, gdzie prawo rzeczowe nie jest oparte na dominacji cywilistycznego dominium, fakt nabycia określonego funkcjonalnie „interest in land”, nie stanowi żadnego problemu psychologicznego.

96 Z. GAWLik, Użytkowanie wieczyste..., s. 23 (podkr. moje).

97 G. Bieniek, W sprawie..., s. 59; A. Cisek, Użytkowanie..., s. 145; B. WierzbowSKI, O przydatności..., s. 624.

98 Por. Grunt i prawo wieczystego użytkowania gruntu w ksieggach rachunkowych, «Zeszyty Metodyczne Księgowości»16/2010.

99 Z. GAWLıK, Użytkowanie wieczyste..., s. 24.

100 Ibidem, s. 27. 
Podkreślić też należy zmianę funkcji społecznej opłaty rocznej. Jak pisał J. Winiarz, w okresie PRL miała ona na celu przechwycenie przez państwo renty gruntowej, a także przerzucenie na użytkowników wieczystych udziału w kosztach wzniesienia infrastruktury ${ }^{101}$. Miała więc charakter redystrybucyjny, łącząc w sobie - w sensie funkcji społecznej, a nie konstrukcji dogmatycznej - elementy podatku od kapitału i opłaty adiacenckiej. Po 1989 r. funkcja opłaty roczna stała sięźródłem dochodu dla gmin (narzędziem pobierania renty kapitałowej ${ }^{102}$ ) jako atrakcyjną ekonomicznie alternatywą względem zbycia własności gruntu przez gminę. Warto w tym kontekście podkreślić krytykę, z jaką spotyka się praktyka korzystania przez publicznych właścicieli gruntów z możliwości podnoszenia wysokości opłaty rocznej w celu maksymalizacji dochodów ${ }^{103}$.

\section{UWAgi PODSUMOWUJĄCE}

Analiza określonej instytucji prawnej jako „reliktu prawnego” mająca przede wszystkim charakter analizy socjologicznoprawnej sensu largo, a nie historyczno-dogmatycznej - zmierza zasadniczo do ustalenia, dlaczego dana instytucja nie została wyeliminowana $\mathrm{z}$ porządku prawnego i nie znikła z praktyki obrotu, lecz właśnie przetrwała transformację ustrojową (w odróżnieniu od innych, które zostały wyeleminowane). Prawo użytkowania wieczystego, powołane do życia w 1961 r., a zatem w zgoła odmiennych warunkach ustroju politycznego i społeczno-gospodarczego niewątpliwie stanowi relikt prawny Polski Ludowej. Przeprowadzona wyżej analiza przemian zarówno konstrukcji dogmatycznej, jak i funkcji społecznej omawianej instytucji miała na celu naświetlenie jej genezy oraz ewolucji, jaką przeszła po 1989 r. Analiza ta ma zaś na celu udzielenie odpowiedzi na fundamentalne pytanie

101 J. Winiarz, Prawo użytkowania..., s. 186.

102 Z. GAWLIK, Użytkowanie..., s. 119.

103 G. BIENIEK, W sprawie..., s. 67. 
o to, dlaczego prawo użytkowania wieczystego nie znikło, lecz istnieje nadal zarówno na płaszczyźnie normatywnej, jak i w praktyce obrotu.

Wydaje się, że aktualny pozostaje pogląd K. Rennera, wedle którego kluczowym aspektem dla przetrwania określonej instytucji prawnej - reliktu prawnego - jest kwestia jej funkcji społecznej. Innymi słowy, dana instytucja reliktowa (in casu, użytkowanie wieczyste) może przetrwać transformację wtedy, gdy nadal istnieje zapotrzebowanie na jej funkcję społeczną a także wtedy, gdy dana instytucja zacznie pełnić nowe funkcje społeczne, na które istnieje zapotrzebowanie w nowych warunkach ustrojowych. Prawo - zarówno law-in-books, jak i law-in-action - nie funkcjonuje bowiem w próżni społecznej, lecz wchodzi w nieustanne interakcje m.in. ze światami polityki i gospodarki.

Odnosząc powyższe do instytucji użytkowania wieczystego można zatem stwierdzić, że instytucja ta przetrwała właśnie dlatego, że jej funkcja społeczna częściowo pozostała aktualna w warunkach gospodarki rynkowej (chodzi o funkcję polegającą na możliwości nabycia przez użytkownika wieczystego stabilnego tytułu prawnego do gruntu, zazwyczaj dla potrzeb budownictwa mieszkaniowego), a częściowo uzyskała nowe, dodatkowe funkcje społeczne, w szczególności z punktu widzenia osób prywatnych i przedsiębiorców (którzy mogą nabywać prawo do gruntu nie tylko dla potrzeb mieszkaniowych, ale także dla celów związanych z działalnością gospodarczą), a także z punktu widzenia jednostek samorządu terytorialnego (które mogą traktować ustanowienie prawa użytkowania wieczystego jako źródło stabilnego, corocznego dochodu do budżetu danej jednostki, zamiast poprzestawania na jednorazowym zysku ze sprzedaży gruntu ${ }^{104}$.

Przykład użytkowania wieczystego jako reliktu prawnego epoki socjalizmu realnego pozwala też na sformułowanie pewnych spostrzeżeń natury ogólnej. Sam bowiem fakt trwania tej instytucji prawnej po 1989 r. dowodzi, że - jak zauważył T. Giaro - pogląd o realnym socjalizmie jako wyłącznie o pewnego rodzaju „zaćmieniu” (blackout) europejskiej historii prawa nosi znamiona stereotypu, a zatem uproszczenia czy wręcz

104 Tym bardziej, że skumulowany zysk z opłaty rocznej niejednokrotnie przekracza wartość rynkową nieruchomości - tak A. CISEK, Użytkowanie wieczyste..., s. 145. 
wypaczenia ${ }^{105}$. Oczywiście faktem jest, że brak wolności politycznej i bardzo trudne nieraz warunki społeczno-ekonomiczne w niewydolnym systemie centralnego planowania i gospodarki nakazowo-rozdzielczej rzutują na sposób postrzegania epoki PRL, w tym kultury prawnej tej epoki ${ }^{106}$. Jest to zjawisko w pełni zrozumiałe. Jeśli dodać do tego liczne przejawy naruszania praworządności, w szczególności w sprawach karnych, negatywny obraz realnego socjalizmu w oczach współczesnych polskich prawników staje się zrozumiały. Tym niemniej nie powinno to przesłaniać faktu, że określone instytucje prawne, nawet jeśli wprowadzone początkowo z pobudek czysto ideologicznych - tak jak to miało miejsce $\mathrm{w}$ wypadku użytkowania wieczystego - z czasem mogą uzyskać niejako samodzielny byt w kulturze prawnej, odrywając się od warunków swej genezy. Po oczyszczeniu prawa użytkowania wieczystego z elementów administracyjnoprawnych ${ }^{107}$ (przy czym proces ten nie uległ jeszcze finalizacji) można uznać je - niezależnie od jego genezy w okresie PRL - za pełnoprawną instytucję prawa prywatnego, nawiązującą do klasycznych rozwiązań cywilistycznych, takich jak emfiteuza czy prawo zabudowy. Jak trafnie zauważył bowiem Z. Gawlik, „nie powinniśmy dokonywać oceny tego prawa [użytkowania wieczystego - R.M.] przez pryzmat historii, jednostkowych zdarzeń czy nawet jego aktualnego kształtu, a tym bardziej nie wydaje się zasadne, żeby okoliczności co do pochodzenia prawa [podkr. R.M.] i jego powszechności miały dyskwalifikować omawianą instytucję."

105 Por. T. Giaro, Some Prejudices about the Legal Tradition of Eastern Europe, w: Comparative Law in Eastern and Central Europe, red. B. SiteK, J.J. SzCzerbowski, A.W. Bauknecht, Newcastle-upon-Tyne 2013, s. 45.

106 R. Mańko, Demons..., s. 66-67.

107 Postulat taki zgłosił m.in. Z. GAwLIK, Użytkowanie wieczyste..., s. 29.

108 Z. Gawlik, Użytkowanie wieczyste..., s. 22. Autor ten trafnie dodaje, że: „Nie można [...] traktować użytkowania wieczystego jedynie jako reliktu epoki realnego socjalizmu i z tego powodu skazywać tego prawa na likwidację. Wejście Polski do UE nie nakłada na nasz kraj konieczności unifikacji prawa rzeczowego z prawem wspólnotowym [...]" (ibidem, s. 24). Należy podkreślić, że w odróznieniu ode mnie, cytowany Autor posługuje się pojęciem „reliktu” jako określenia ocennego (pejoratywnego). W pozostałym zakresie oczywiście się z nim zgadzam. 
Co więcej, przy odpowiednim dalszym zliberalizowaniu unormowań składających się na tę instytucję (np. umożliwieniu ustanawiania użytkowania wieczystego na gruntach osób fizycznych i prawnych ${ }^{109}$ czy doprecyzowaniu w k.c. zasad indeksacji opłaty rocznej, aby lepiej chronić interes użytkowników wieczystego ${ }^{110}$ ), można oczekiwać, że stanie się ona nowoczesną i elastyczną instytucją prawa prywatnego, dopasowaną do oczekiwań i potrzeb uczestników obrotu.

\section{PRAWO UŻYTKOWANIA WIECZYSTEGo JAKO POZOSTAŁoŚĆ PO EPOCE SOCJALIZMU REALNEGO - UJĘCIE SOCJOLOGICZNOPRAWNE}

\section{Streszczenie}

Prawo użytkowania wieczystego zostało wprowadzone do polskiego porządku prawnego w 1961 r., a zatem w okresie tzw. realnego socjalizmu. Do przyczyn wprowadzenia tej instytucji prawnej zaliczyć należy istotne czynniki polityczne i ideologiczne, a w szczególności realizację koncepcji, wedle której państwo socjalistyczne nie powinno zbywać gruntów na rzecz osób fizycznych i prawnych. Poza funkcjami polityczno-ideologicznymi, omawiana instytucja pełniła także określone funkcje społeczno-gospodarcze, do których należało m.in. udostępnianie osobom fizycznym oraz spółdzielniom mieszkaniowym gruntów pod budownictwo mieszkaniowe. Po transformacji ustrojowej w 1989 r. instytucja użytkowania wieczystego nie została wyeliminowana z polskiego porządku prawnego, występuje też w obrocie prawnym. W perspektywie socjologicznoprawnej wynika to przede wszystkim $z$ dopasowania funkcji społecznych omawianej instytucji do zmienionych warunków po transformacji ustrojowej.

109 Tak np. Z. Gawlık, Użytkowanie wieczyste..., s. 28. Autor ten trafnie uzasadnia postulat m.in. niskimi cenami nieruchomości w Polsce na tle innych państw UE.

110 Por. Ibidem, s. 31. 
The Right of Perpetual Usufruct as a Survival of the Period of Actually Existing Socialism: A Socio-Legal Perspective

\section{Summary}

The right of perpetual usufruct was introduced to the Polish legal order in 1961, i.e. during the period of so-called actually existing socialism. Amongst the reasons of its introduction were political and ideological factors, and in particular the conception, according to which a socialist state should not alienate the ownership of land to natural and legal persons. Apart from political and ideological functions, the institution in question also fulfilled a number of socio-economic functions, inter alia it enabled natural persons and housing cooperatives to gain access to land for housing construction. Following the transformation of 1989, the institution of perpetual usufruct was not eliminated from the Polish legal order and it also continues to function in practice. From a socio-legal perspective, this continuity is a result of the adaptation of the social functions of the institution in question to the changed conditions folloing the systemic transformation.

Słowa kluczowe: użytkowanie wieczyste, relikt prawny, funkcja społeczna, transformacja ustrojowa

Keywords: perpetual usufruct, legal survival, social function, systemic transformation

\section{Bibliograhy}

Bieniek G., W sprawie przyszłości użytkowania wieczystego, [w:] Ars et usus.

Ksiegga pamiątkowa ku czci Sędziego Stanisława Rudnickiego, Warszawa 2005 Bogucka I., Funkcje prawa. Analiza pojęcia, Kraków 2000

BUTLER W.E., Soviet Law, London 1983

Cesarski M., Dorobek materialny społdzielczości mieszkaniowej w Polsce, [w:] Historia i przyszłość społdzielczości mieszkaniowej w Polsce red. Z. GotFALSKI, Warszawa 2011

CiseK A., Użytkowanie wieczyste [w:] System prawa prywatnego, IV: Prawo rzeczowe ${ }^{2}$, red. E. GNIEWEK, Warszawa 2007 
GaWLıK Z., Użytkowanie wieczyste 'de lege ferenda', [w:] Czterdzieści lat kodeksu cywilnego, red. M. SAwCzuk, Kraków 2006

GAWLIK Z., Użytkowanie wieczyste w świetle wypowiedzi Profesora Jerzego Ignatowicza, «Annales UMCS - Sectio G» 60.1/2013

Giaro T., Roman Law Always Dies With a Codification, [w:] Roman Law and European Legal Culture, red. A. DęBIŃsKi, M. JoŃCA, Lublin 2008

Giaro T., Some Prejudices about the Legal Tradition of Eastern Europe, [w:] Comparative Law in Eastern and Central Europe, red. B. SiteK, J.J. SzCZERBowski, A.W. BAuknecht, Newcastle-upon-Tyne 2013

Lesage M., Le droit soviétique, Paris 1975

Lityński A., Prawo Rosji i ZSRR 1917-1991 czyli historia wszechzwiąkowego komunistycznego prawa (bolszewików). Krótki kurs, Warszawa 2012

Machnikowska A., Prawo własności w Polsce w latach 1944-1981. Studium historycznoprawne, Gdańsk 2010

Mańко R., „We Do Not Recognise Anything "Private«": Public Interest and Private Law Under the Socialist Legal Tradition and Beyond, [w:] Private Interest and Public Interest in European Legal Tradition, red. B. SITEK I IN., Olsztyn 2015

Mańко R., Demons of the Past? Legal Survivals of the Socialist Legal Tradition in Contemporary Polish Private Law, [w:] Law and Critique in Central Europe: Questioning the Past, Resisting the Present, red. R. MańKo, C.S. CerCel, A. Sulikowski, Oxford 2016

MаŃко R., Legal Survivals: A Conceptual Tool for Analysing Post-Transformation Continuity of Legal Culture, [w:] Tiesību efektivitāte postmodernā sabiedrībā, red. J. RozenfELDS I IN., Riga 2015

MaŃko R., Relikty w kulturze prawnej. Uwagi metodologiczne na tle pozostałości epoki socjalizmu realnego $w$ polskim prawie prywatnym, «Przegląd Prawa i Administracji» 102/2015

Mańко R., The Cooperative Member's Proprietary Right to an Apartment: A Legal Survival of the Period of Actually Existing Socialism in Polish Private Law, «Zeszyty Prawnicze»15.4/2015

MańKo R., Transformacja ustrojowa a ciagłość instytucji prawnych - uwagi teoretyczne, «Zeszyty Prawnicze» 16.2/2016

MаŃко R., Wybrane relikty prawne epoki realnego socjalizmu w polskim prawie cywilnym - analiza zmiany funkcji społecznej instytucji prawnych w następstwie transformacji ustrojowej, «Studia Iuridica» 66/2016

Marx K., Engels F., The Communist Manifesto, London 2002 [1848] 
Pietrzy Kowski K., [w:] Kodeks cywilny. Komentarz do artykułów 1-449"11, red.

K. Pietrzy kowski, Warszawa 2005

Podleś P., Przekształcanie prawa użytkowania wieczystego w prawo własności, Warszawa 2007

Redelbach A., Wronkowska S., Ziembiński Z., Zarys teorii państwa i prawa, Warszawa 1994

Renner K., The Institutions of Private Law and Their Social Functions, ttum. A. SCHWARzschild, London-Boston 1976 [1904].

Rudziński A.W., A Comparative Study of Polish Property Law, [w:] Polish Civil Law, I, red. D. LAsoK, Leiden 1973

SCHÖNFELDER B., The evolution of law under communism and post-communism: a system-theory analysis in the spirit of Luhmann, «Financial Theory \& Practice» 40.3/2016

Wierzbowski B. O przydatności użytkowania wieczystego [w:] in Honeste vivere... Księga, pamiątkowa ku czci Profesora Władysława Bojarskiego, Toruń 2001

Winiarz J., Prawo użytkowania wieczystego, Warszawa 1970. 